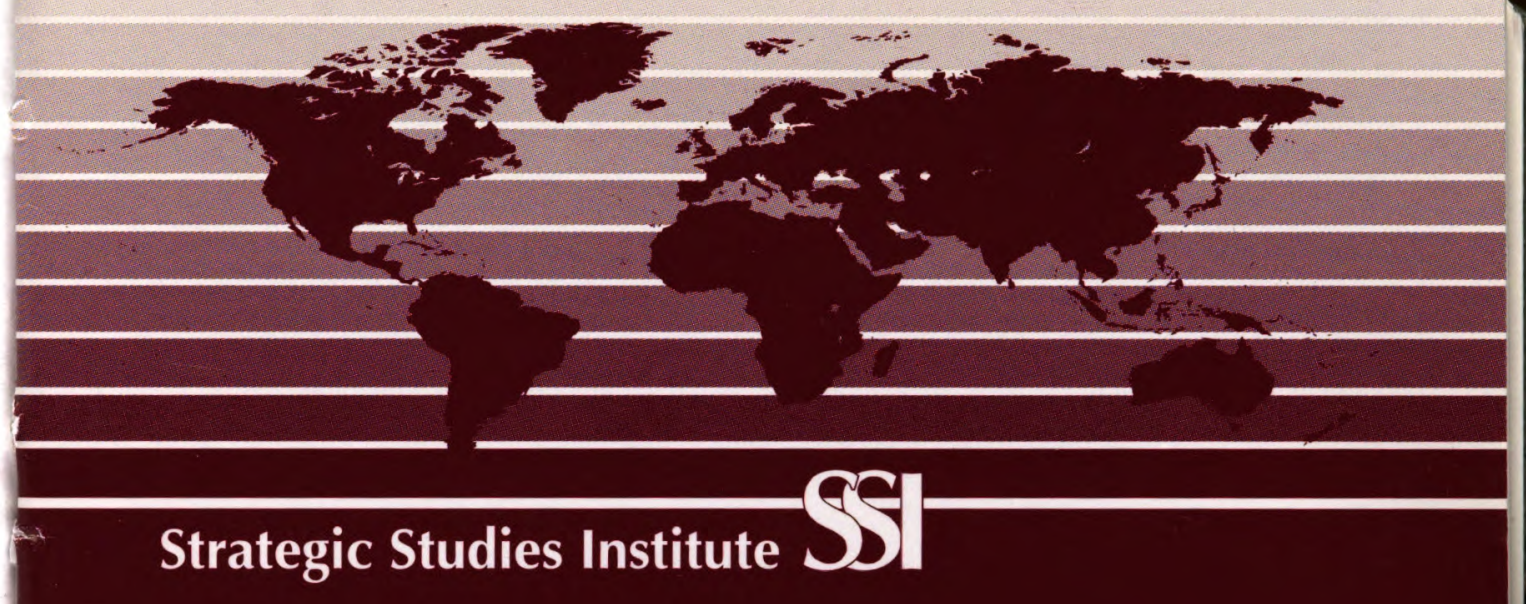

\title{
DECEPTION 101 - PRIMER ON DECEPTION
}

\author{
Joseph W. Caddell
}

